Nova Biologica Reperta 7(4): 457-467 (2021)

Print ISSN: 2423-6330/Online ISSN: 2476-7115

https://nbr.khu.ac.ir; Kharazmi University Press; DOI: 10.29252/nbr.7.4.457

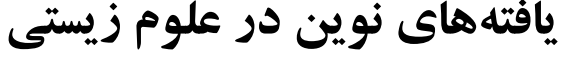

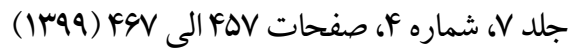

انتشارات دانشگاه خوارزمى

جكيده. Phelipanche pouyanii به عنوان يك گَونه جديد از استان خراسان جنوبى واقع در شرق ايران معرفى مى شود. صفات ريخت شناسى تشخيصى

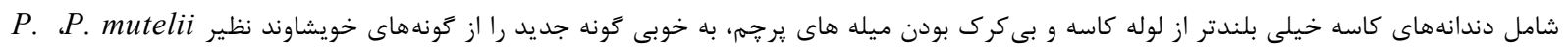
جد Pana و angustelaciniata

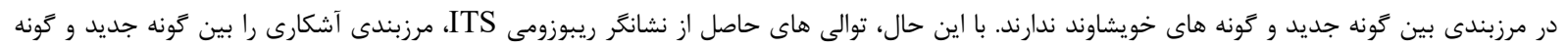
هاى خويشاوند نشان مى دهند.

وازههاى كليدى. آرايهشناسى تلفيقى، بومى، تبارزايى، حفاظت، خراسان جنوبى

\title{
Phelipanche pouyanii (Orobanchaceae), a new species from Iran
}

\section{Seyedeh Zahra Moosavi Parsai ${ }^{1}$, Jamil Vaezi ${ }^{1,2}$, Hamid Ejtehadi ${ }^{1}$, Farshid Memariani $^{2}$ \& Mohammad Reza Joharchi \\ ${ }^{1}$ Department of Biology, Faculty of Sciences, Ferdowsi University of Mashhad, Mashhad, Iran; ${ }^{2}$ Research Centre for Plant Sciences, Ferdowsi University of Mashhad, Mashhad, Iran \\ Corresponding author: Jamil Vaezi, vaezi@um.ac.ir}

\begin{abstract}
Phelipanche pouyanii is described here as a new species from South Khorassan Province, East of Iran. Its diagnostic morphological features are the calyx teeth being far longer than the calyx tube and staminal filaments being glabrous. These characters clearly differentiated the new species from its closely related taxa, i.e., $P$. mutelii, $P$. angustelaciniata and P. nana. Results obtained from the pollen and seed micromorphological characters showed no significant taxonomic value in the delimitation of the new species from its closely related species. The internal transcribed spacer (ITS) sequences, however, showed sufficient differences to delineate the new species from its closely related species.
\end{abstract}

Keywords. conservation, endemic, integrated taxonomy, phylogeny, South Khorassan 


\section{INTRODUCTION}

The family Orobanchaceae comprises approximately 90 genera and 2060 species worldwide, excluding a few non-parasitic autotrophs (McNeal et al., 2013). The number of species of the holoparasitic genus Orobanche L. sensu lato varies from 36 (Schiman-Czeika, 1964), 33 (Gilli, 1979) and 39 (Saeidi Mehrvarz et al., 2010), up to 41 (Iranshahr, 2008, referred to Novopokrovsky, 1958) in Iran. These species belong to two traditionally accepted sections Trionychon Wallr. (= Phelipanche Pomel) and Orobanche (= sect. Osproleon Wallr.). However, according to the morphological, karyological and molecular studies, these sections have been treated as separate genera, Phelipanche and Orobanche, respectively (Holub, 1990; Schneeweiss et al., 2004a, b; Carlón et al., 2005; Weiss-Schneeweiss et al., 2006; Park et al., 2008; noted also by Joel, 2009; Li et al., 2019).

The representatives of the genus Orobanche s.l. occupy the arid, semi-arid to humid tropical habitats (Molau, 1995). The distribution of the members of the genus depends on very narrow to broad ranges of host plants parasitized by them (FernándezAparicio et al., 2009). Saeidi Mehrvarz et al. (2010) listed the common host plants which are parasitized by the Orobanche s.l. species in Iran; Some of Orobanche s.l. species have been adapted to parasitize a wide range of host plants.

During field investigations and taxonomic revision of the genus Orobanche s.l. in the Provinces of North Khorassan, Razavi Khorassan and South Khorassan, east and northeast of Iran, we discovered an unknown specimen belonging to the genus Phelipanche. At the first glance, it appeared to be phenotypically similar to $P$. nana (Reut.) Soják and $P$. angustelaciniata (Gilli) Holub. For instance, the characters "branched stem", "densely hairy style in the lower half" and "densely villous stigma" are common with those of $P$. nana, whereas "branched stem", "moderately dense inflorescence", "bract length", "linearlanceolate shape of scales", "the lower corolla lip longer than the upper one", and "indumentum type of corolla" revealed its close affinity to $P$. angustelaciniata. Moreover, its branched stem and corolla length and color seem to be similar with those of P. mutelii (F.W.Schultz) Pomel. Consequently, comparative morphological studies revealed that the unknown specimen indeed belong to an undescribed species.

In this work, we describe and illustrate $P$. pouyanii as a new species using morphological, palynological, seed surface micromorphological and molecular data. In addition, the relationships of the new species with its morphological relatives ( $P$. nana, $P$. mutelii and $P$. angustelaciniata) are discussed.

\section{MATERIALS AND METHODS}

Plant specimens were first collected by M.R. Joharchi during a fieldwork in Birjand, South Khorassan Province (Iran) in 2012. Herbarium vouchers from field-collected specimens were deposited in the Ferdowsi University of Mashhad Herbarium (FUMH, acronym according to Thiers, 2016). The specimens were checked against the relevant literature (Schiman-Czeika, 1964; Gilli, 1979; Iranshahr, 2008; Saeidi Mehrvarz \& Shahi Shavon, 2017). Moreover, we included one individual of $P$. nana collected from South Khorassan Province, Tabas, Chirook village (Zokaei 729-FUMH), one specimen of P. mutelii sampled from South Khorassan Province, SE Birjand (Joharchi \& Zangooei 10784-FUMH) (incorporated in the morphological comparison) and one individual of $P$. angustelaciniata collected from South Khorassan Province, Tabas, Ozabgoo, Alimorad mine (Ayatollahi \& Zangooei 13874FUMH) in the present study. Furthermore, in order to perform the molecular study, we included herbarium or silica-dried leaves of the new species, $P$. angustelaciniata and $P$. orientalis (Beck) Soják (0004711-W, collected from Golestan National Park, E. Golestan province, Iran). We incorporated the new molecular data obtained from the present study with those belonging to some closely related Phelipanche species including $P$. nana and $P$. mutelii obtained from GenBank.

For the morphological descriptions, the fully developed structures of plant materials were examined. Due to darkening of the colors during desiccation, coloration characters were directly noted and photographed in the field. Flowers, bracts, and bracteoles were rehydrated before morphological examinations and measurements were made.

Pollen morphology of $P$. pouyanii, $P$. nana and $P$. angustelaciniata was examined by means of light microscopy (LM) and scanning electron microscopy (SEM). Pollen grains were obtained from dried specimens used in the morphological study. The pollen grains were acetolysed following Erdtman (1960). They were observed with an Olympus microscope model BX-50 (Olympus Co., Tokyo, Japan) equipped with an oil-immersion objective. The characters "polar axis", "equatorial axis", "exine thickness", and "the ratio polar axis/equatorial axis" were measured for at least 30 pollen grains of each taxon. Pollen size and shape classes were used following Erdtman (1952). For SEM, the acetolyzed pollen grains were first dehydrated in a graded ethanol series. Then, they were mounted on aluminum stubs and coated with the gold-palladium alloy in a sputter coater (SC 
7620, Quorum Technologies Ltd, UK). Subsequently, they were observed and photographed with a VP LEO 1450 SEM at $20 \mathrm{KV}$ (Zeiss Co., Oberkochen, Germany). The SEM micrographs were used for descriptions of the pollen grains following the terminology of Erdtman (1952).

The length, width, shape, epidermal cell shape, the anticlinal and the periclinal walls, and testa pattern of seeds were measured and described for 20 seeds per taxon using SEM (model VP LEO 1450 at 20 $\mathrm{KV}$ ). Seed preparation for SEM was similar to that of pollen as described above.

Total DNA was extracted using the standard CTAB method (Doyle \& Doyle, 1987). Each included taxon, i.e., $P$. pouyanii, $P$. angustelaciniata, and $P$. orientalis, was represented by one voucher specimen. The forward and reverse universal primers ITS5 and ITS4 (White et al., 1990), respectively were used to amplify the ITSnrDNA region. The amplification was performed in $25 \mu \mathrm{L}$ volumes containing $12.5 \mu \mathrm{L}$ of Taq DNA polymerase Master Mix Red 2X (Amplicon A/S, Denmark), $100 \mu \mathrm{mol} / \mathrm{L}$ of each primer, and ca. $200 \mathrm{ng}$ genomic DNA. PCA amplification was carried out under the following conditions: a preliminary denaturation step at $95{ }^{\circ} \mathrm{C}$ for 5 min followed by 35 cycles of denaturation at $95{ }^{\circ} \mathrm{C}$ for $30 \mathrm{~s}$, annealing at $55^{\circ} \mathrm{C}$ for $45 \mathrm{~s}$, elongation at $72{ }^{\circ} \mathrm{C}$ for $1 \mathrm{~min}$ and a final extension at $72{ }^{\circ} \mathrm{C}$ for $7 \mathrm{~min}$. PCR-product purification and direct sequencing were performed using Macrogen's sequencing service (Macrogen Inc., Korea). Sequencher ver. 5.2.4 (Gene Codes Inc., Ann Arbor, Michigan) was used to edit sequences.

ITS sequences obtained from the present study $(P$. pouyanii, MW524124; $P$. angustelaciniata, MW524122; $P$. orientalis, MW524123) were combined with some closely related Phelipanche sequences available in GenBank ( $P$. aegyptiaca Pomel, KC811164; P. gratiosa (Webb \& Berthelot) Carlón, G.Gómez, M.Laínz, Moreno Mor., Ó.Sánchez \& Schneew, EU581793; P. mutelii (F.W.Schultz) Pomel, AY209340; P. lavandulacea Pomel, EU581718; $P$. inexspectata Carlón, G.Gómez, M.Laínz, Moreno Mor., Ó.Sánchez \& Schneew, AY960739; P. cf. iberica (Beck) Soják, LT715380; P. rosmarina (Beck) Banfi, Galasso, Soldano, MK026668; P. ramosa (L.) Pomel, KY513946; P. nana, AY209318; P. oxyloba (Reut.) Soják, AY209319; P. tunetana (Beck) Soják, AY209324 and Orobanche alba Stephan ex Willd., AY209249 was included as an outgroup. The integrated sequences were aligned using Clustal W (Thompson et al., 1994) as implemented in BioEdit Sequence Alignment Editor (Hall, 1999) followed by manual corrections. SeqState ver. 1.25 (Müller,
2005) was used to code the indels using the "simple indel coding" method (Simmons \& Ochoterena, 2000). Evolutionary model selection was carried out to determine the best-fitted nucleotide substitution model for the dataset using MrModeltest 2.2 (Nylander, 2004). Subsequently, the Bayesian inference was run for one million generations for the ITS matrix as implemented in MrBayes 3.2.1 (Ronquist et al., 2012). The first $25 \%$ of generations were discarded as determined by Tracer ver. 1.4 (Rambaut \& Drummond, 2007). Trees were visualized using TreeView ver. 1.6.6 (Page, 2001). In general, the resulting ITS phylogenetic tree showed low resolution, particularly among the species $P$. ramosa, $P$. rosmarina, $P$. cf. iberica, $P$. inexspectata, $P$. pouyanii, $P$. angustelaciniata, $P$. oxyloba, $P$. nana and, P. tunetana. Therefore, to demonstrate more sequence resolution, the network analysis was used for the species mentioned above using the statistical parsimony on the dataset with gaps treated as missing data and a $92 \%$ connection limit (Tempelton et al., 1992). This analysis was performed in the TCS program ver. 1.21 (Clement et al., 2000).

\section{RESULTS}

By the presence of bracteole and connected calyx parts, the new species is clearly nested within the genus Phelipanche. The close relationships and affinity among $P$. pouyanii, $P$. mutelii, $P$. angustelaciniata, and $P$. nana are well supported by their similar morphological traits such as the branched stem, bracteole length, stamen and style length, scale length/width, the length of the longest calyx dent in comparison with the length of the calyx tube, the number of calyx dents, sparse indumentum of petal margin, and mucronate and glabrous anthers. However, Phelipanche pouyanii can be distinguished from $P$. mutelii, $P$. angustelaciniata and $P$. nana by multiple morphological characters, summarized in Table 1.

Among the diagnostic vegetative and reproductive morphology ical traits in $P$. pouyanii are subulate floral bract, bract being as long as or shorter than the calyx, the calyx teeth far longer than the calyx tube, bracteoles lanceolate to linear, and glabrous filaments. These morphological characters are used frequently in the diagnosis of Orobanche s.l. species (e.g., Domina \& Soldano, 2015; Piwowarczyk, 2015).

The results obtained from palynological and seed micromorphological investigation of the current study are presented in Figures 3-4 and Table 2. Clearly, the basic type of pollen grain of Phelipanche (radially symmetrical trizonocolpate, Abu Sbaih et al., 1994) is also found to be present in the specimens studied. According to Erdtman (1952), the pollen shape of $P$. pouyanii in monads is 
prolate-spheroidal (P/E: 1.01-1.14), whereas that of $P$. angustelaciniata and $P$. nana is subprolate $(\mathrm{P} / \mathrm{E}$ : 1.15-1.33) and prolate (P/E: 1.34-2.00), respectively. Abu Sbaih et al. (1994) reported the oblate-spheroidal pollen shape for $P$. nana. This discrepancy may reflect intraspecific variation in the pollen shape. Based on the results, the surface sculpture of pollen in $P$. pouyanii, $P$. angustelaciniata and $P$. nana is found to be scabrate-perforate (Fig. 1).

The seed micromorphological characters of $P$. pouyanii, $P$. angustelaciniata and $P$. nana as shown by SEM (Fig. 2) are reviewed in Table 2. The results demonstrate that the seed surface sculpture of the three species is alveolate as shown for Orobanche owerinii Beck and $O$. reticulata Wallr. by Zare \& Dönmez (2013). The seed dimension almost differentiates $P$. pouyanii from $P$. angustelaciniata in which the seed length and width in $P$. pouyanii is nearly two times greater than those in $P$. angustelaciniata, while these characters cannot distinguish $P$. pouyanii from $P$. nana. In all the species studied, the testa pattern and seed shape are isodiametric to irregular and ovate-elliptic, respectively. The anticlinal walls are raised with a smooth surface. Nevertheless, top of the anticlinal walls is slightly waved in $P$. pouyanii and $P$. nana. Moreover, the periclinal wall in the three species is reticulate-perforate with a sparsely papillate surface pattern.

In overall, our results indicate that the micromorphological characteristics resulted from pollen and seed surface studies are of no conclusive taxonomic value in the differentiation of Phelipanche species studied, while they can be helpful if combined with other morphological features to have a correct circumscription of each species. This finding is in accordance with the works of Abu Sbaih et al. (1994), Plaza et al. (2004), Halamski (2011), and Zare \& Dönmez (2013). In contrast, in a micro-morphological framework, Parsapanah \& Saeidi-Mehrvarz (2015) showed that the palynological characters are useful in delimitation of some Pedicularis species incorporated in the study.

Table 1. Diagnostic morphological characters among three closely related Phelipanche species included in the present study.

\begin{tabular}{|c|c|c|c|c|}
\hline Character/Species & P.pouyanii & P. mutelii & P. angustelaciniata & P. nana \\
\hline Inflorescence & moderately dense & dense & moderately dense & very dense \\
\hline Scale & $\begin{array}{l}8-10 \mathrm{~mm} \text { long, } \\
\text { linear-lanceolate }\end{array}$ & $\begin{array}{l}\text { up to } 17 \mathrm{~mm} \text { long, } \\
\text { lanceolate } \\
\text { subulate }\end{array}$ & $\begin{array}{l}10-13 \mathrm{~mm} \text { long, } \\
\text { linear-lanceolate }\end{array}$ & $\begin{array}{l}5-13 \mathrm{~mm} \text { long, } \\
\text { ovate }\end{array}$ \\
\hline Bract & $\begin{array}{l}9-14 \mathrm{~mm} \text { long, } \\
\text { narrow } \\
\text { lanceolate }\end{array}$ & $\begin{array}{lr}5-12 \quad \mathrm{~mm} & \text { long, } \\
\text { subulate } & \text { or } \\
\text { lanceolate } & \end{array}$ & $\begin{array}{l}\text { 13-15 } \mathrm{mm} \text { long, } \\
\text { ovate }\end{array}$ & $\begin{array}{lr}7-14 \mathrm{~mm} & \text { long, } \\
\text { lanceolate } & \text { or } \\
\text { subulate } & \end{array}$ \\
\hline Bracteoles & $\begin{array}{l}\text { lanceolate to } \\
\text { linear }\end{array}$ & linear or subulate & $\begin{array}{l}\text { narrow lanceolate to } \\
\text { long subulate }\end{array}$ & linear or subulate \\
\hline Calyx & $\begin{array}{l}10-14 \mathrm{~mm} \text { long, } \\
\text { dents very longer } \\
\text { than tube }\end{array}$ & $\begin{array}{l}7-12 \mathrm{~mm} \text { long, dents } \\
\text { equal, a little shorter } \\
\text { or longer than tube }\end{array}$ & $\begin{array}{l}10-17 \mathrm{~mm} \text { long, dents } \\
\text { longer than tube }\end{array}$ & $\begin{array}{lll}9-13 & \mathrm{~mm} & \text { long, } \\
\text { dents equal } & \text { or a } \\
\text { little longer than } \\
\text { tube }\end{array}$ \\
\hline Corolla & $\begin{array}{l}17.5-23 \mathrm{~mm} \text { long, } \\
\text { cylindrical- } \\
\text { infundibuliform }\end{array}$ & $\begin{array}{l}18-22 \mathrm{~mm} \text { long, } \\
\text { infundibular }\end{array}$ & $\begin{array}{l}10-17 \quad \mathrm{~mm} \text { long, } \\
\text { cylindrical- } \\
\text { infundibuliform }\end{array}$ & $\begin{array}{lr}14-17 \mathrm{~mm} & \text { long, } \\
\text { campanulate } & \text { or } \\
\text { infundibular } & \end{array}$ \\
\hline Filament & Glabrous & sparsely villous & sparsely villous & sparsely villous \\
\hline Host & $\begin{array}{l}\text { Prunus armeniaca } \\
\text { (Juvenile) }\end{array}$ & $\begin{array}{l}\text { Nicotiana tabacum, } \\
\text { Parrotia persica, } \\
\text { Prunus dulcis, } \\
\text { Prunus armeniaca, } \\
\text { Cousinia multiflora, } \\
\text { Carpinus spp., Salvia } \\
\text { spp., Stachys spp. }\end{array}$ & Prunus spp. & $\begin{array}{l}\text { Artemisia } \text { spp., } \\
\text { Centaurea } \text { spp., } \\
\text { Astragalus spp., } \\
\text { Eryngium spp., } \\
\text { Prunus scoparia }\end{array}$ \\
\hline
\end{tabular}



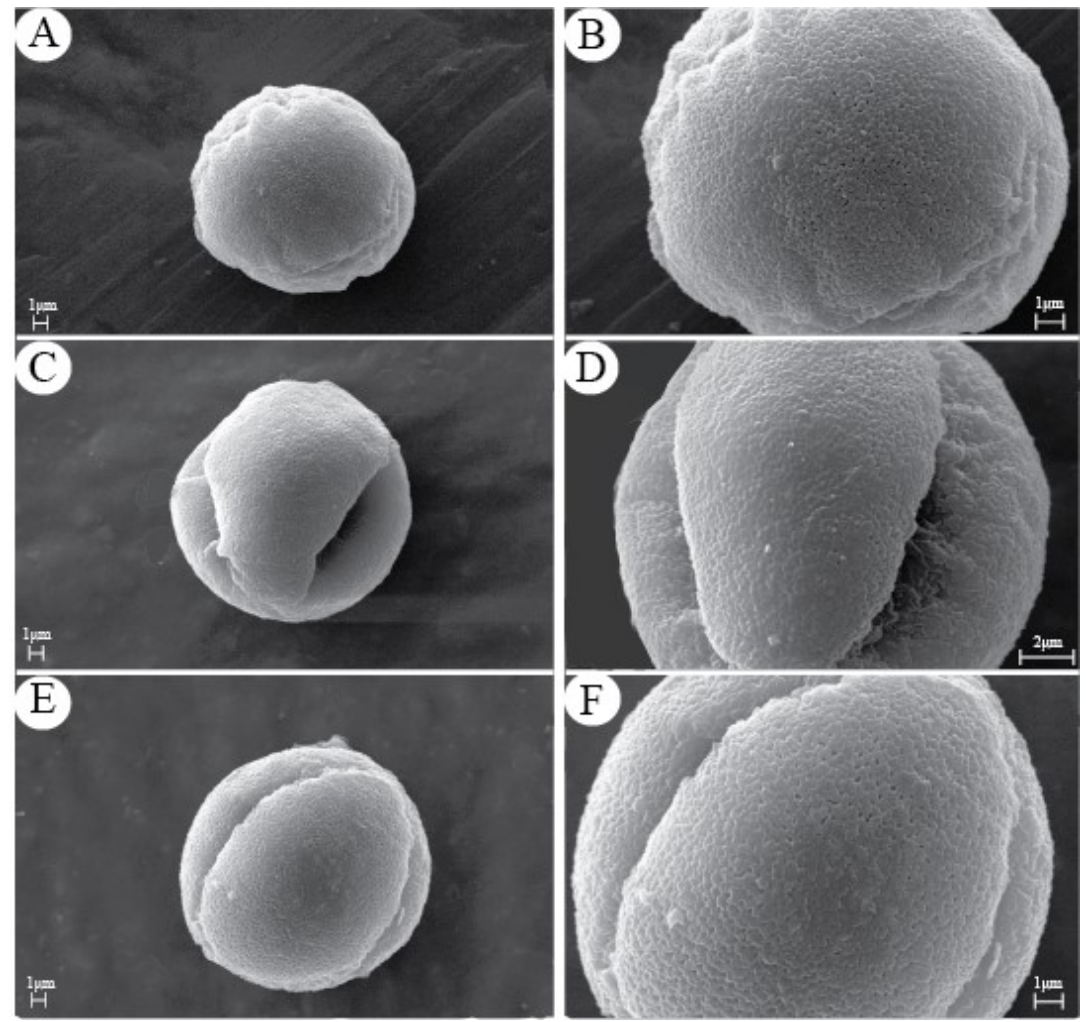

Figure 1. Scanning electron micrographs of the pollen grains of Phelipanche species. A-B. P. pouyanii (Joharchi 44746-FUMH). C-D. P. angustelaciniata (Ayatollahi \& Zangooei 13874-FUMH). E-F. P. nana (Zokaei 729-FUMH)
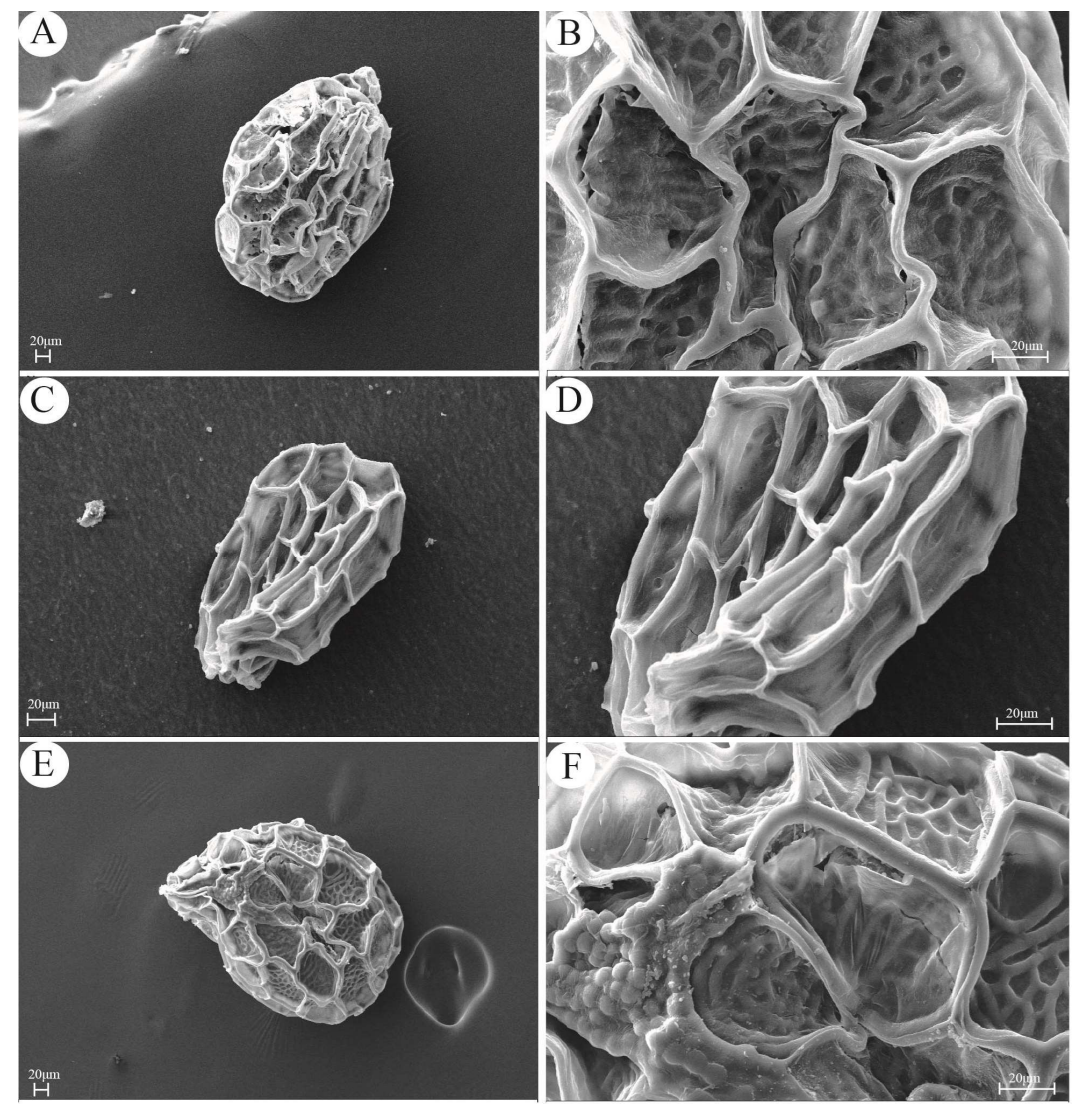

Figure 2. Scanning electron micrographs of seeds in Phelipanche species showing the shape (left) and ornamentation (right). A-B. P. pouyanii (Joharchi 44746-FUMH). C-D. P. angustelaciniata (Ayatollahi \& Zangooei 13874-FUMH). E-F. P. nana (Zokaei 729-FUMH). 
Table 2. Details of pollen and seed micromorphological characters of Phelipanche species included in the present study.

\begin{tabular}{|c|c|c|c|}
\hline Character/Species & P. pouyanii & P. angustelaciniata & P. nana \\
\hline Polar axis $(\mathrm{P}, \mu \mathrm{m})$ & 26.6 & 22.5 & 27.1 \\
\hline Equatorial axis $(\mathrm{E}, \mu \mathrm{m})$ & 24.9 & 17.9 & 17.3 \\
\hline $\mathrm{P} / \mathrm{E}$ & 1.07 & 1.26 & 1.57 \\
\hline Exine thickness $(\mu \mathrm{m})$ & 1.35 & 2.86 & 3.4 \\
\hline Pollen aperture & Tricolpate & tricolpate & tricolpate \\
\hline Pollen sculpture & scabrate-perforate & scabrate-perforate & scabrate-perforate \\
\hline Pollen shape & prolate-spheroidal & subprolate & prolate \\
\hline Seed length $(\mu \mathrm{m})$ & 320 & 180 & 340 \\
\hline Seed width $(\mu \mathrm{m})$ & 220 & 110 & 200 \\
\hline Periclinal wall & reticulate-perforate & reticulate-perforate & $\begin{array}{l}\text { reticulate-perforate- } \\
\text { papilate }\end{array}$ \\
\hline Testa pattern & $\begin{array}{l}\text { isodiametric } \\
\text { irregular }\end{array}$ & isodiametric to irregular & $\begin{array}{l}\text { isodiametric } \\
\text { irregular }\end{array}$ \\
\hline Anticlinal wall & smooth to waved & Smooth & smooth to waved \\
\hline Seed shape & ovate-elliptic & ovate-elliptic & ovate-elliptic \\
\hline
\end{tabular}

Totally, 637 nucleotide characters (including coded gaps) related to 15 ITS sequences were integrated into the Bayesian analysis, of which 487 were constant, 131 parsimony-uninformative and the 19 remaining nucleotide sites were parsimonyinformative. Analysis of the ITS sequences using Bayesian inference with the SYM nucleotide substitution model (based on the Akaike information criterion) resulted in a $50 \%$ majority rule consensus tree (Fig. 3). The tree shows that all the Phelipanche species incorporated in the study form a monophyletic group with a strong posterior probability support $(\mathrm{PP}=1.00)$ with respect to the outgroup.

The Phelipanche species, however, make two subclades I and II (Fig. 3) where the new species, $P$. pouyanii, is nested within the subclade II. Phelipanche mutelii which is morphologically similar to $P$. pouyanii, is located within the subclade I. However, the meaningful signals provided by the ITS data do not support a close relationship between these two species.

In general, the Bayesian phylogenetic tree shows relatively low resolution among the Phelipanche species. Therefore, to provide more resolution, the members of the subclade II were reanalyzed using the network reconstruction algorithms. The results obtained from the simplified network (Fig. 4) show that no identical ribotypes were identified among the species included in the network analysis. The closest related species to $P$. pouyanii is $P$. cf. iberica connected with two mutational steps. Furthermore, two morphologically related species, $P$. nana and $P$. angustelaciniata are connected to $P$. pouyanii with three mutational steps. In spite of the relatively low sequence resolution resulted among the Phelipanche species, the network analysis has provided an adequate power to differentiate $P$. pouyanii as an independent species from its relatives. However, usage of chloroplastic markers might provide a phylogenetic relationship among the species under study with more resolution in comparison with that based on the nrDNA (ITS) data.

\section{Description of the new species}

Phelipanche pouyanii Joharchi \& Vaezi, sp. nov. (Figs. 5, 6)

Type: IRAN. South Khorassan Province: SW Birjand, Bagheran Mountains, southwest of Omar Shah Dam. N: 32 49' 39.6" E: 59 $19^{\circ} 47.5^{\prime}, 1700$ m, 6 May 2012, Joharchi 44746 (Holotype: FUMH; Isotype: FUMH).

Plant $18-27 \mathrm{~cm}$ tall with branched stem at base, purple; scales $8-10 \mathrm{~mm}$ long, towards tip gradually 


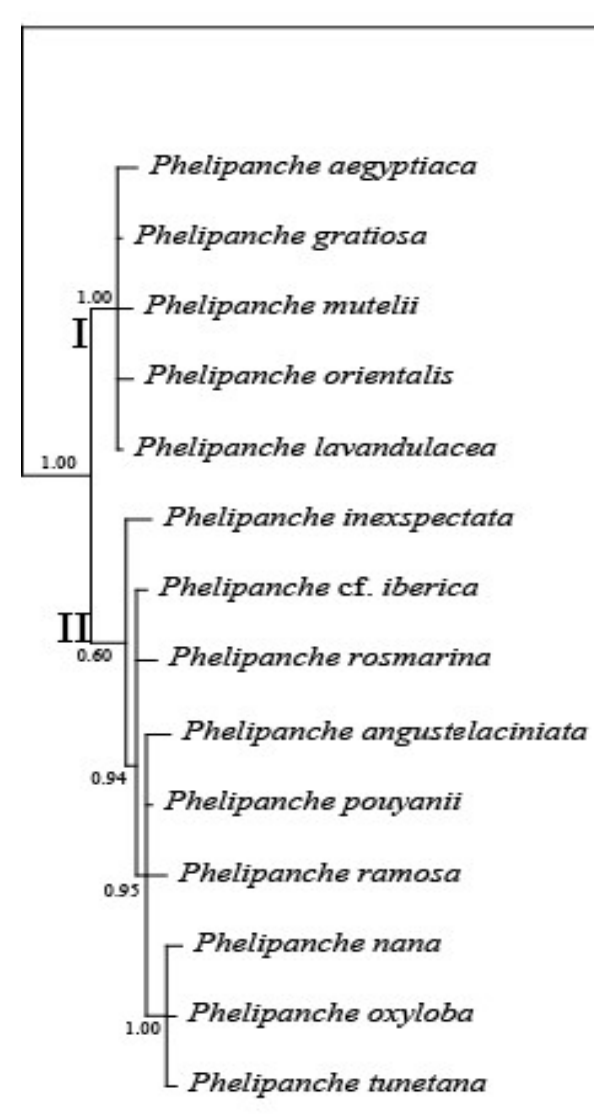

Orobanche alba

0.1

Figure 3. Phylogenetic tree of some Phelipanche species resulting from the Bayesian analysis of their ITS data. Subclade II comprises the unresolved sequences which are expanded in Figure 6. Numbers above or below branches are posterior probabilities.

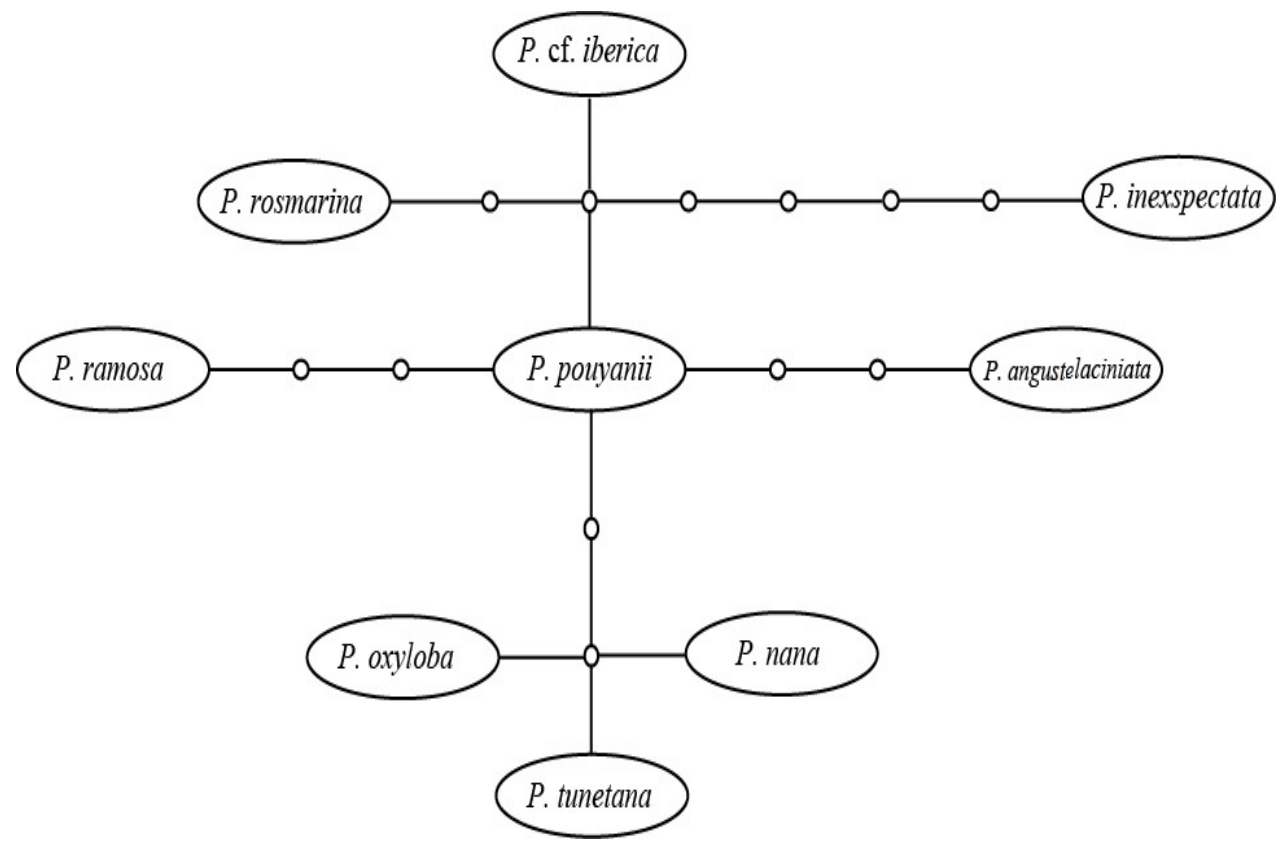

Figure 4. Simplified ribotype network of the ITS dataset using all ribotypes included in the subclade II of Figure 5. The small circles indicate unsampled ribotypes. 


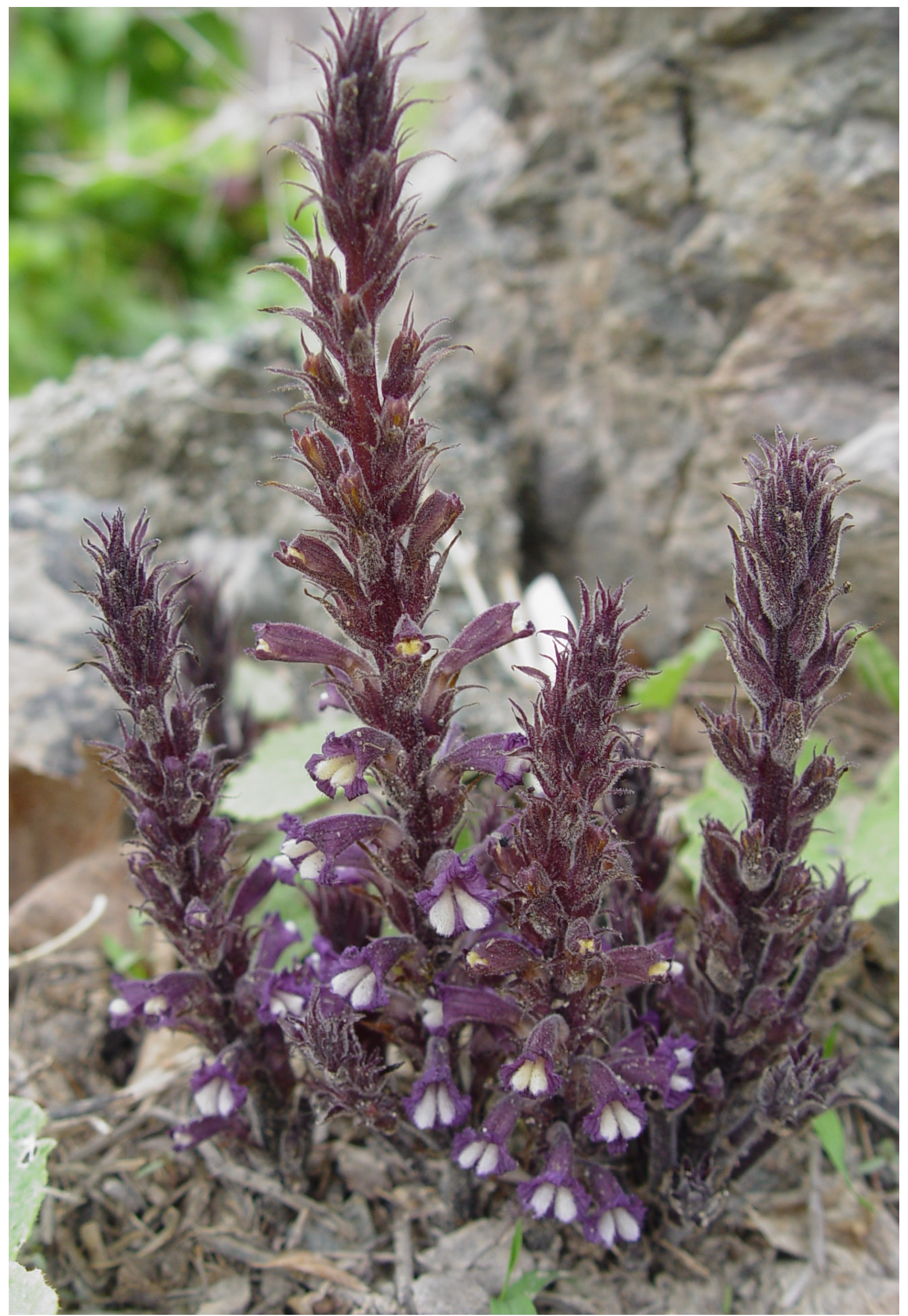

Figure 5. Phelipanche pouyanii in its natural habitat (Joharchi 44746-FUMH, photo by M.R. Joharchi). 


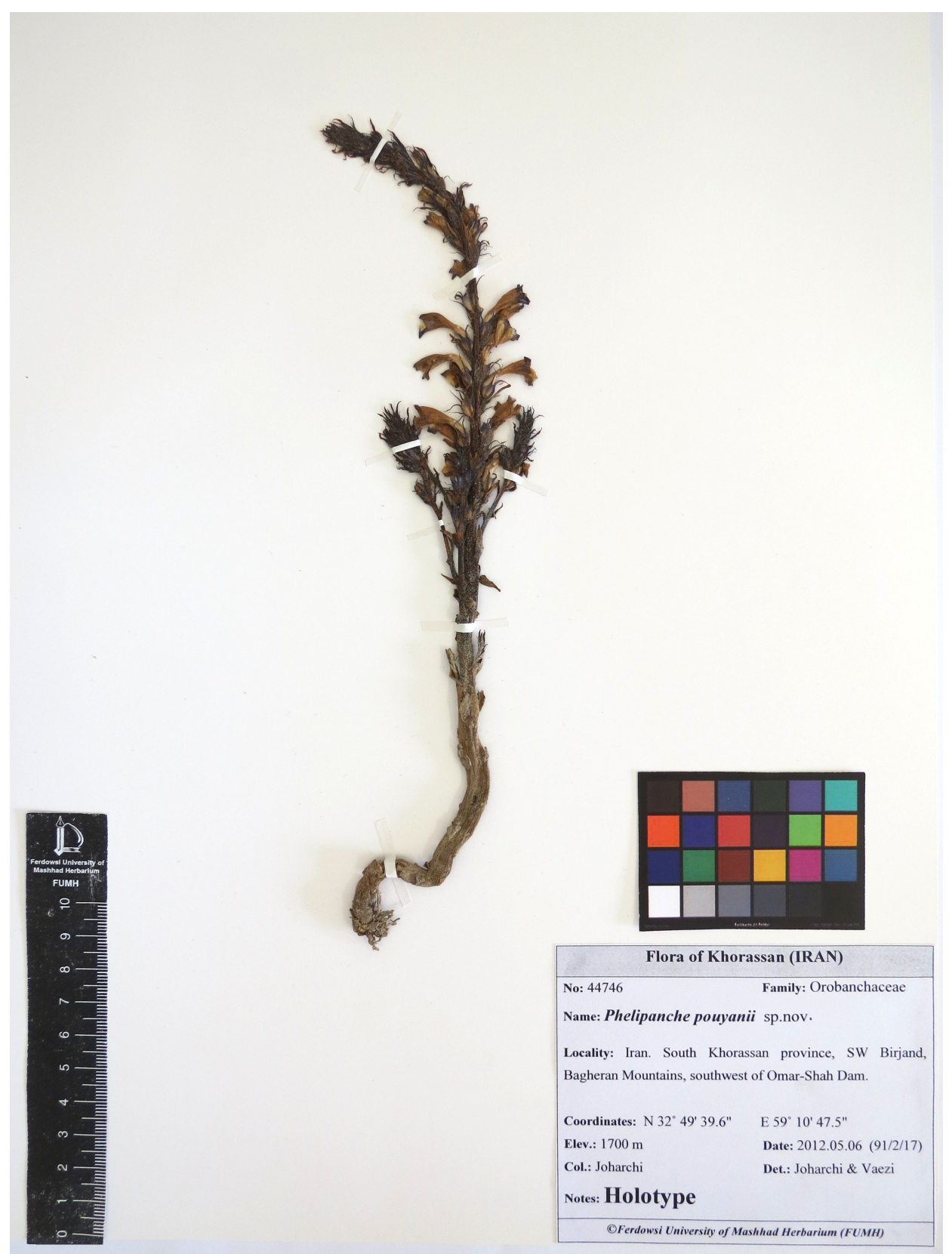

Figure 6. Holotype of Phelipanche pouyanii sp. nov. deposited in the FUMH herbarium (Joharchi 44746).

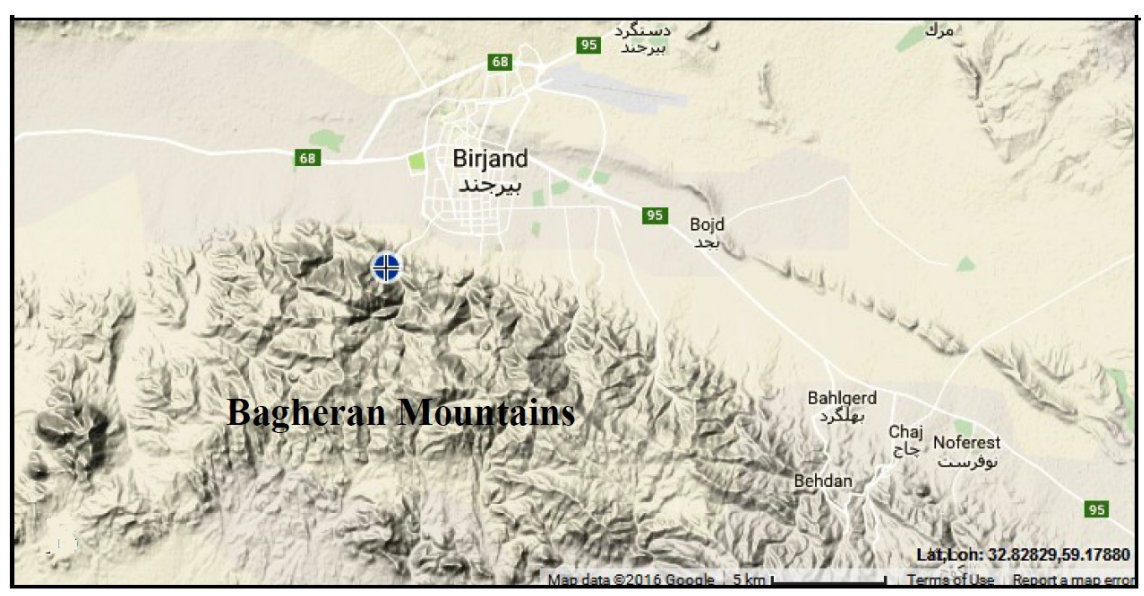

Figure 7. Distribution map of Phelipanche pouyanii in Bagheran Mountains, SW Birjand. 
narrow; inflorescence 10-12 cm long, fairly dense, triangular (base slightly broadened) forming a spike; flowers pedicellate, pedicel length in lower flowers up to $6 \mathrm{~mm}$, in upper flowers $2-3 \mathrm{~mm}$; bracts narrowly ovate-lanceolate, $9-14 \mathrm{~mm}$ long, as long as or shorter than calyx, glandular pubescent; bracteols linear-lanceolate, glandular pubescent; calyx cylindrical to campanulate $10-14 \mathrm{~mm}$ long, dents strongly developed, very longer than the tube, triangular in base, linear to filiform at the tip; corolla $17.5-23 \mathrm{~mm}$ long, pale yellow and inflated at the base, cylindrical-infundibuliform, deeply purple, lobes of the upper lip ovate-triangular with acute apex, lobes of the lower lip ovate-elliptic and longer than the upper lip, all lobes entire at margin, the lower lip between lobes densely pubescent; stamen 4-5 $\mathrm{mm}$ above the base of the corolla, filaments glabrous as the base, densely glandular-pubescent near the anthers; pollen aperturate, trisulcatetricolpate, exine ornamentation scabrate-perforate, polar axis $26.6 \mu \mathrm{m}$, equatorial axis $24.9 \mu \mathrm{m}$, exine thickness $1.35 \mu \mathrm{m}$; style pubescent at the base, stigma densely pubescent; capsule 4-5 mm long; seed $0.358 \times 0.247 \mathrm{~mm}$, spheroidal, testa pattern irregularly triangle, anticlinal wall smooth to ribbed. Etymology: The species is named in honor of $\mathrm{Mr}$. Mohsen Pouyan, an eminent botanist in Birjand, South Khorassan province, where the species was collected.

Habitat and Host: Phelipanche pouyanii grows in a narrow valley in southern slopes of Bagheran Mountains in an area which is planted mainly by apricot and apple orchards. Based on current data, it is exclusively parasitic on Prunus armeniaca L.

Conservation status:- So far, the new species is known only from the type locality. Accordingly, it has a very restricted distribution range in the east of Iran (Fig. 7). Based on IUCN criteria and categories for Red Listing, the Data Deficient (DD) category is applied to taxa with insufficient information mainly due to poorly known distribution data, however, using the criterion $\mathrm{D}$ which deals with very small or restricted populations (IUCN, 2016), Phelipanche pouyanii is assessed here as Vulnerable (VU D1,2).

\section{Key to the closely related species of the present study}

1. Corolla length shorter than $17 \mathrm{~mm}$......... 2

- $\quad$ Corolla length longer than $17 \mathrm{~mm} \mathrm{..........} 3$

2. Upper and lower lips of corolla nearly equal in size, corolla limbs ovate, apiculate ..................................................... P. nana (Reut.) Soják

Upper lips of corolla very shorter than lower lips, corolla limbs linear .P. angustelaciniata (Gilli) Holub
3. Calyx dents equal, a little shorter or longer than tube, filaments sparsely villous ....................... mutelii (F.W.Schultz) Pomel - $\quad$ Calyx dents very longer than tube, filaments glabrous at base and towards apex ................. ..P. pouyanii Joharchi \& Vaezi, sp. nov.

\section{ACKNOWLEDGEMENT}

This work is a part of M.Sc. thesis (Research project No. 3/26622) of the first author. We appreciate the late Dr. Shahryar Saeidi Mehrvarz and Dr. Golshan Zare for their checking and confirming the taxonomic status of the type specimen as a new species. The authors also thank vice president for Research and Technology of Ferdowsi University of Mashhad for financial support.

\section{REFERENCES}

Abu Sbaih, H.A., Keith-Lucas, S.L. \& Jury, F.L.S. 1994. Pollen morphology of the genus Orobanche L. (Orobanchaceae). Botanical Journal of Linnean Society 116: 305-313.

Clement, M., Posada, D. \& Crandall, K.A. 2000. TCS: a computer program to estimate gene genealogies. Molecular Ecology 9: 1657-1659.

Domina, G. \& Soldano, A. 2015. Orobanche apuana (Orobanchaceae) a new species endemic to Italy. Phytotaxa 207: 163-171.

Doyle, J.J. \& Doyle, J.L. 1987. A rapid DNA isolation procedure for small quantities of fresh leaf tissue. Phytochemical Bulletin 9: 11-15.

Erdtman, G. 1952. Pollen morphology and plant taxonomy. Angiosperms: an introduction to palynology. Almqvist \& Wiksell, Stockholm, 539 pp.

Erdtman, G. 1960. The acetolysis method. A revised description. Svensk Botanisk Tidskrift 54: 561-564.

Fernández-Aparicio, M., Flores, F. \& Rubiales, D. 2009. Recognition of root exudates by seeds of broomrape (Orobanche and Phelipanche) species. Annals of Botany 103: 423-431.

Gilli, A. 1979. Die Orobanchaceen der "Flora Iranica". Candollea 34: 279-305.

Halamski, A.T. 2011. Orobanche hederae Vaucher ex Duby (Orobanchaceae) phenotypic plasticity and seed micromorphology. Bulletin mensuel de la Société Linnénne de Lyon 80: 195-203.

Hall, T.A. 1999. BioEdit: a user-friendly biological sequence alignment editor and analysis program for Windows 95/98/NT. Nucleic Acids Symposium Series 41: 95-98.

Holub, J. 1990. Some taxonomic and nomenclatural changes within Orobanche s.l. (Orobanchaceae). Preslia 62: 193-198.

Iranshahr, M. 2008. The parasitic and semi-parasitic flowering plants of Iran. Rostaniha 31: 2-59. (in Persian).

IUCN. 2016. Guidelines for Using the IUCN Red List Categories and Criteria. Version 12. Prepared by the Standards and Petitions Subcommittee. Available 
from: http://www.iucnredlist.org/documents/RedList Guidelines.pdf (accessed 8 May 2016).

Li, X., Feng, T., Randle, C. \& Gerald M. Schneeweiss, G.M. 2019. Phylogenetic relationships in Orobanchaceae inferred from low-copy nuclear genes: Consolidation of major clades and identification of a novel position of the non-photosynthetic Orobanche clade sister to all other parasitic Orobanchaceae. Frontiers in Plant Science 10: 1-14.

McNeal, J.R., Bennett, J.R., Wolfe, A.D. \& Mathews, S. 2013. Phylogeny and origins of holoparasitism in Orobanchaceae. American Journal of Botany 100: 971-983.

Molau, U. 1995. Reproductive ecology and biology. In: Press, M.C. \& Graves, J.D. (eds.) Parasitic plants. Chapman \& Hall, London. Pp. 141-176.

Müller, K. 2005. SeqState-primer design and sequence statistics for phylogenetic DNA data sets. Applied Bioinformatics 4: 65-69.

Novopokrovsky, I.V. 1958. Orobanchaceae. In: Schishkin, B.K. (ed.) Flora of the U.S.S.R. 23. Moskva and Leningrad (English translation by Koeltz Scientific Books in 2000), pp. 36-140.

Nylander, J.A.A. 2004. MrModeltest v2. Program distributed by the author, Evolutionary Biology Centre, Uppsala University. http://www.abc.se/ nylan der/.

Page, D.M. 2001. TreeView (Win32) Version 1.6.6. http://taxonomy.zoology.gla.ac.uk/rod/rod.html.

Park, J.M., Manena, J.F., Colwell, A.E. \& Schneeweiss, G.M. 2008. A plastid gene phylogeny of the non-photosynthetic parasitic Orobanche L. (Orobanchaceae) and related genera. Journal of Plant Research 121: 365-376.

Parsapanah, S. \& Saeidi-Mehrvarz, Sh. 2015. Stigma morphological study and numerical taxonomy of genus Pedicularis L. (Orobanchaceae) in Iran. Nova Biologica Reperta 1: 57-66.

Piwowarczyk, R. 2015. Orobanche zajaciorum (Orobanchaceae): a new species from the Caucasus. Phytotaxa 201: 214-220.

Plaza, L., Fernandez, I., Juan, R., Pastor, J. \& Pujadas, A. 2004. Micromorphological studies on seeds of Orobanche species from the Iberian Peninsula and the Balearic Islands, and their systematic significance. Annals of Botany 94: 167178.

Rambaut, A. \& Drummond, A.J. 2007. Tracer v1.5, available from http://beast.Bio.Ed.Ac.Uk/tracer.

Roquist, F., Teslenko, M., Van der Mark, P., Ayres, D.L., Darling, A., Höhna, S., Larget, B., Liu, L., Suchard, M.A. \& Huelsenbeck, J.P. 2012. MrBayes
3.2: efficient Bayesian phylogenetic inference and model space. Systematic Biology 61: 539-542.

Saeidi Mehrvarz, Sh., Torabi, A. \& Aghabeigi, F. 2010. Notes on the genus Orobanche (Orobanchaceae) in Iran. Iranian Journal of Botany 16: 107-113.

Saeidi Mehrvarz, Sh. \& Shahi Shavon, R. 2017. Flora of Iran, No. 86 (Orobanchaceae). Institue of Forest and Rangelands, Tehran. (in Persian).

Schiman-Czeika, H. 1964. Orobanchaceae. In: Rechinger, K.H. (ed.). Flora Iranica, vol. 5. Akademische Druck- und Verlagsanstalt, Graz, 25 pp.

Schneeweiss, G.M., Colwell, A., Park, J.M., Jang, C.G. \& Stuessy, T.F. 2004a. Phylogeny of holoparasitic Orobanche (Orobanchaceae) inferred from nuclear ITS-sequences. Molecular Phylogenetics and Evolution 30: 465-478.

Schneeweiss, G.M., Palomeque, T., Colwell, A.E. \& Schneeweiss, H.W. 2004b. Chromosome numbers and karyotype evolution in holoparasitic Orobanche L. (Orobanchaceae) and related genera. American Journal of Botany 91: 439-448.

Simmons, M.P. \& Ochoterena, H. 2000. Gaps as characters in sequence-based phylogenetic analyses. Systematic Biology 49: 369-381.

Templeton, A.R., Crandall, K.A. \& Sing, C.F. 1992. A cladistic analysis of phenotypic associations with haplotypes inferred from restriction endonuclease mapping and DNA sequence data. III. Cladogram estimation. Genetics 132: 619-633.

Thiers, B. 2016. Index Herbariorum: A global directory of public herbaria and associated 602 staff. Available from: http://sweetgum.nybg.org/ih/ (accessed 14 October 2016).

Thompson, J.D., Higgins, D.G. \& Gibson, T.J. 1994. ClustalW: improving the sensitivity of progressive multiple sequence alignment through sequence weighting, position-specific gap penalties and weight matrix choice. Nucleic Acids Research 22: 46734680.

Weiss-Schneeweiss, H., Greilhuber, J. \& Schneeweiss, G.M. 2006. Genome size evolution in holoparasitic Orobanche (Orobanchaceae) and related genera. American Journal of Botany 93: 148-156.

White, T.J., Bruns, T., Lee, S. \& Taylor, J. 1990. Amplification and direct sequencing of fungal ribosomal RNA genes for phylogenetics. In: Innis, M.A., Gelfand, D.H., Sninsky, J.J. \& White, T.J. (eds.). PCR Protocols: A guide to methods and applications. Academic Press, San Diego, pp 315-322.

Zare, G. \& Dönmez, A.A. 2013. Two new records of the genus Orobanche (Orobanchaceae) from Turkey. Turkish Journal of Botany 37: 597-603.

How to cite this article:

Moosavi Parsai, S.Z., Vaezi, J., Ejtehadi, H., Memariani, F. \& Joharchi, M.R. 2021. Phelipanche pouyanii (Orobanchaceae), a new species from Iran. Nova Biologica Reperta 7: 457-467. 